\title{
(R)-3-[(S)-1-Carboxy-5-(4-Piperidyl) pentyllamino-4-Oxo-2,3,4,5- Tetrahydro-1,5-Benzothiazepine-5-Acetic Acid (CV-5975): A New Potent and Long-Lasting Inhibitor of Angiotensin Converting Enzyme
}

\author{
Yoshiyuki INADA, Katsumi ITOH*, Kazuhide KAMIYA*, \\ Hirosada SUGIHARA* and Kohei NISHIKAWA \\ Biology Laboratories and *Chemistry Laboratories, Central Research Division, \\ Takeda Chemical Industries, Ltd., Juso, Yodogawa-ku, Osaka 532, Japan
}

Accepted March 21988

\begin{abstract}
The synthetic design and the biological activities of structurally new angiotensin converting enzyme (ACE) inhibitors, $(R)$-3-amino-4-oxo-2,3,4,5tetrahydro-1,5-benzothiazepine-5-acetic acid derivatives, are described. A number of compounds in this series showed potent ACE inhibitory activity in vitro and in vivo. Structure-activity studies indicated that a piperidyl moiety on the amino group at the 3 -position in this series conferred long-lasting ACE inhibitory activity and that the duration of activity depended on the length of the carbon chain in the 1 -carboxy- $\omega$-(4-piperidyl)alkyl group. (R)-3-[(S)-1-carboxy-5-(4-piperidyl)pentyl] amino-4-oxo-2,3,4,5-tetrahydro-1,5-benzothiazepine-5-acetic acid (CV5975 ) was selected as the most promising ACE inhibitor for further studies because of its marked inhibitory activity.
\end{abstract}

Angiotensin converting enzyme (ACE) (peptidyldipeptide hydrolase, EC 3.4.15.1) is an exopeptidase that cleaves dipeptides from the carboxyl-terminal of various peptide substrates (1-4). Two reactions catalyzed by ACE may play a role in blood pressure regulation: conversion of the inactive decapeptide angiotensin $\mathrm{I}(\mathrm{A}-\mathrm{I})$ to the potent vasopressor octapeptide, angiotensin II (AII) $(2,3)$, and inactivation of the vasodepressor nonapeptide bradykinin (4). The importance of one or both of these reactions in hypertensive disease has been greatly clarified in recent years by the development of specific, orally active inhibitors of ACE. Captopril (5-7) and enalapril (8-10) are potent, orally active ACE inhibitors, which have been shown to be effective for the treatment of hypertension in humans (11-14). Since the discovery of these drugs, many analogues have been prepared (15-18). and their structure-activity relationships have been studied. Petrillo and Ondetti (19) proposed a model of the ACE active site to
Which peptide substrates and inhibitors bind. However, the spatial orientation of the enzyme binding sites and the inhibitor conformation required for binding have not been clarified. One way to approach the problem is to restrict the possible conformations of $\mathrm{ACE}$ inhibitors by synthesizing rigid molecules. We have already reported a new ACE inhibitor, delapril $\mathrm{HCl}$ ( $\mathrm{CV}-3317$. Compound 1a in Fig. $1)$. which is more potent and has longerlasting action than captopril $(20,21)$. In the present paper, the design and the structureactivity relationships of synthetic (R)-3amino-4-oxo-2,3,4,5-tetrahydro-1,5,-benzothiazepine derivatives are described.

\section{Materials and Methods}

1. Conformational analysis: The energyminimized conformations of delapril $\mathrm{HCl}(\mathrm{CV}$ 3317), enalapril and (R)-3-amino-4-oxo2,3,4,5 - tetrahydro - 1,5 - benzothiazepine - 5 acetic acid were generated by computer calculation using programs MM2 and MNDO.

2 . Inhibition of pressor response to angio- 


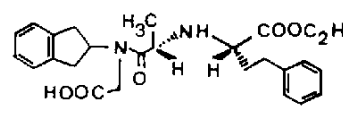

1a (Delapril)

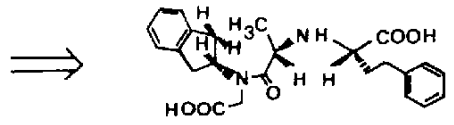

$1 \mathrm{~b}(\mathrm{CV}-3317-\mathrm{COOH})$

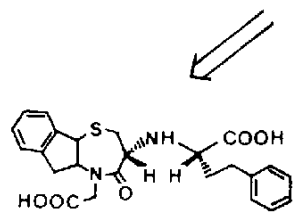

2

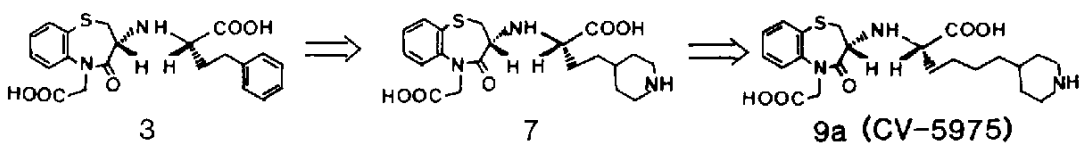

Fig. 1. A new angiotensin converting enzyme inhibitor. CV-5975, derived from delapril.

tensin I (A-I) in rats: Male Sprague-Dawley rats (SD:JCl). weighing $300-400 \mathrm{~g}$. were anesthetized with sodium pentobarbital (50 $\mathrm{mg} / \mathrm{kg}$. i.p.) and were prepared with an aortic catheter and a caval catheter inserted via the right femoral artery and vein, respectively. Both catheters were passed subcutaneously to the neck and were exposed there. After surgery, the animals were placed into plastic cages and allowed freedom of movement; tap water was provided ad libitum, but food was withheld. Experiments were started on the next morning after surgery. The aortic cannula was connected to a pressure transducer, and the mean blood pressure was recorded on a polygraph. The pressor responses to $\mathrm{A}-\mathrm{I}(300 \mathrm{ng} / \mathrm{kg})$ and A-II $(100 \mathrm{ng} / \mathrm{kg})$ were measured after injection of each compound into the femoral vein. The response to each compound was measured twice, and the average response to each drug was used as the control in all calculations. After blood pressure had returned to the pretreatment level, ACE inhibitors were administered p.o. or I.V. to the rats. Thereafter, the A-I and A-II challenges were repeated at set times. Inhibition by the test compounds of the pressor response to A-I was determined. The A-II challenge was used to correct the percent inhibition value, based on the change of vascular responsiveness during the course of the experiment.

3. Inhibition of ACE in vitro: Angiotensin converting enzyme ( $A C E$ ) was prepared from the lungs of albino male rabbits as previously described (20). Lung homogenates were prepared by a slight modification of the method described by Wallace et al. (22) in that the tissue was homogenized in 9 volumes of $100 \mathrm{mM}$ borate $\mathrm{HCl}$ buffer containing 300 $\mathrm{mM} \mathrm{NaCl}(\mathrm{pH} 8.3)$, and then the homogenates were centrifuged for $25 \mathrm{~min}$. The filtered supernatant was used as the source of crude ACE. Enzyme activity was determined by a slight modification of the spectrophotometric method described by Cushman and Cheung (3) in which the conversion of the synthetic substrate hippuryl-L-histidyl-Lleucine $(\mathrm{HHL})$ to hippuric acid was measured. The assay mixture contained $5 \mathrm{mM} \mathrm{HHL}, 300$ $\mathrm{mM} \mathrm{NaCl}, 100 \mathrm{mM}$ borate- $\mathrm{HCl}$ buffer, test compound $\left(10^{-8} \mathrm{M}\right)$ and the crude ACE in a total volume of $250, \mu l$. The mixture was incubated at $37^{\circ} \mathrm{C}$ for $60 \mathrm{~min}$. The reaction was terminated by adding $1 \mathrm{~N} \mathrm{HCl}(150 / l)$, and the hippuric acid formed was extracted with 2 volumes of ethyl acetate and its concentration determined from its absorbance at $228 \mathrm{~nm}$.

4. Drugs: Angiotensin I, angiotensin II and hippuryl-L-histidyl-L-leucine were obtained 
from the Protein Research Foundation; hippuric acid was from Sigma: heparin was from Shimizu Pharmaceutical Co; and pentobarbital- $\mathrm{Na}$ (Somnopentyl) was from Pitman Moore. The test compounds, (R)-3-amino-4oxo-2,3,4,5-tetrahydro-1.5-benzothiazepine5-acetic acid derivatives, and CV-3317-
$\mathrm{COOH}$ were synthesized as described in previous reports $(23,24)$.

\section{Results}

1. Conformational analysis: Figure 2 shows the computer-drawn structures of alanyl proline, alanyl indanyl glycine, and (R)-3-
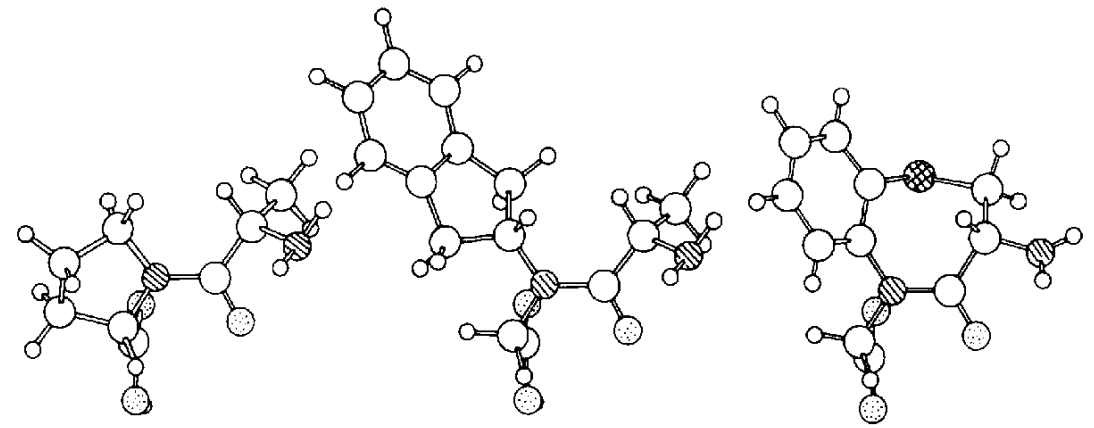

Fig. 2. Comparison of the conformation of alanyl proline (left), alanyl indanyl glycine (center) and (R)3-amino-4-oxo-2.3.4.5-tetrahydro-1,5-benzothiazepine-5-acetic acid (right). S: $9.0 ;, N ; O$, C: $\mathrm{O}, \mathrm{H}$.

Table 1. Duration of inhibitory action of compounds on angiotensin I (A-1) induced pressor response in rats<smiles>[R]CC[C@H](C)N[C@H]1CSc2ccccc2N(CC(=O)O)C1=O</smiles>

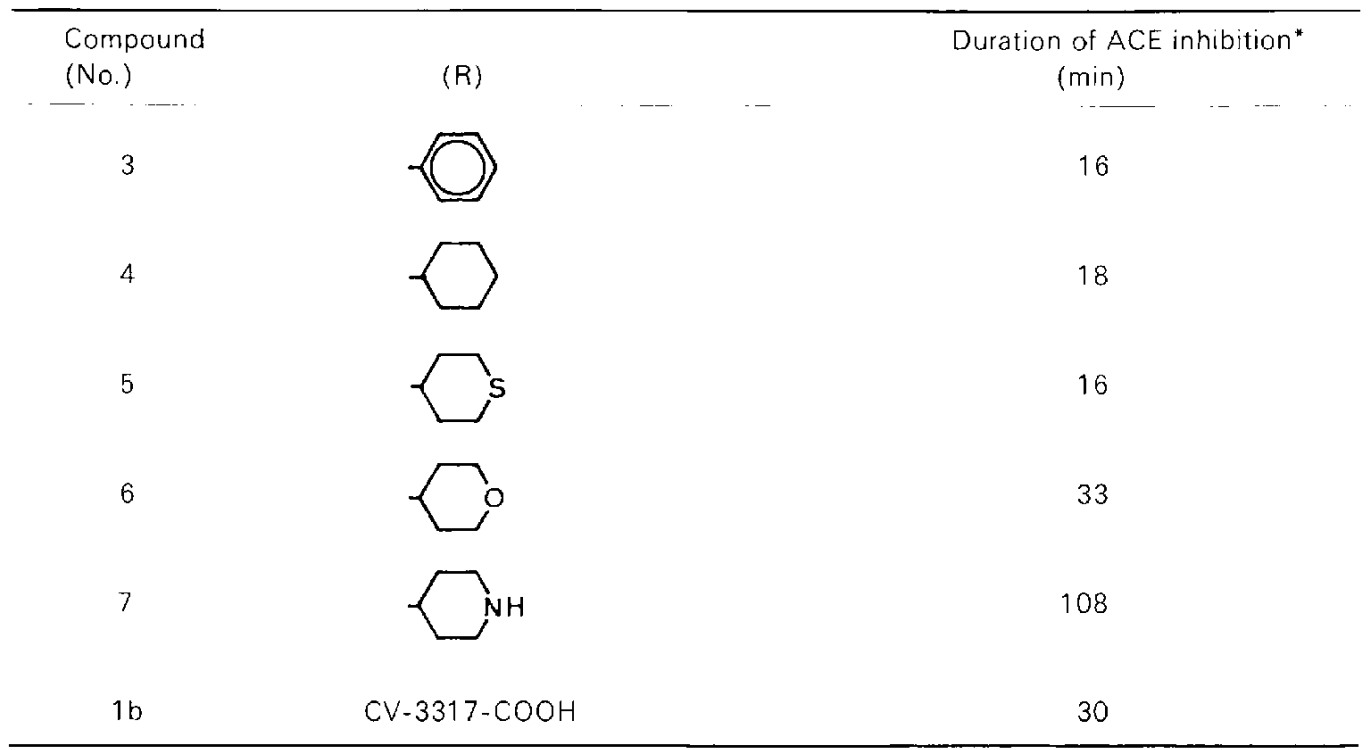

*Duration of ACE inhibition is designated as the time $(\mathrm{min})$ required for the inhibited $\mathrm{A}$-l-induced pressor response to recover to $50 \%$ of the control values for $A_{-}-1$-induced pressor response. 
amino-4-oxo-2,3,4.5-tetrahydro-1,5-benzothiazepine-5-acetic acid according to the Dreiding model. Examination of these conformations indicates that they all have the same spatial orientation. The functional groups such as carboxy, amide, amino and hydrophobic moieties are located in the same positions in these 3 compounds.

2. Structure-activity relationship: The ACE inhibitory activities of compounds $3,4,5,6$ and 7 are given in Table 1. Intravenous administration of these compounds at 0.3 $\mathrm{mg} / \mathrm{kg}$ potently inhibited the $\mathrm{A}-\mathrm{I}$ induced pressor response, but the duration of activity varied (Fig. 3). Compound 7 , a piperidyl derivative, displayed longer-lasting activity than the corresponding phenyl derivative (compound 3).

As shown in Fig. 4, in addition to compound 7, other piperidyl derivatives (compound $8,9 a, 10$ and 11 ) had potent and long lasting activity in vivo, when administered intravenously at $0.3 \mathrm{mg} / \mathrm{kg}$. The duration of activity after i.v. administration closely correlated with the length of the carbon chain in the 1-carboxy-w-(4-piperidyl)alkyl group. and out of the series of benzothiazepine derivatives examined, maximum duration was observed with the 1 -carboxy-5-(4-piperidyl)pentylamino derivative (compound $9 \mathrm{a}, \mathrm{CV}$ -
5975)

3. ACE inhibitory activity of CV-5975 and its stereoisomers: CV-5975 (compound 9a) and its 3 stereoisomers (compounds $9 \mathrm{~b}, 9 \mathrm{c}$ and $9 \mathrm{~d}$ ) were evaluated for their inhibitory activity on rabbit lung $A C E$ and $A-1$ pressor

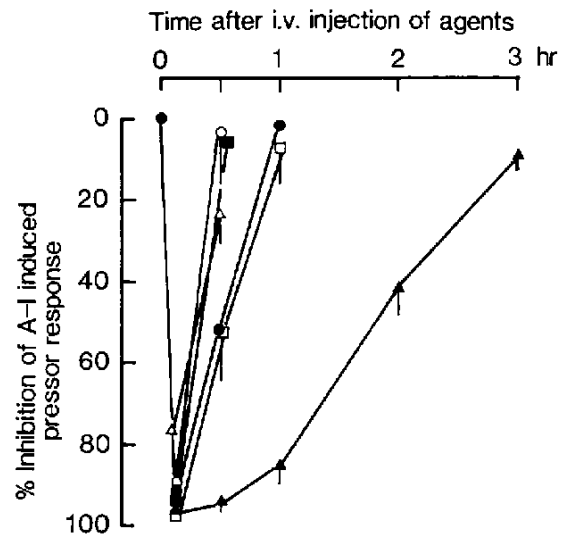

Fig. 3. Inhibitory effects of (R)-3-amino-4-oxo$2,3,4,5$ - tetrahydro - 1,5 - benzothiazepine - 5 - act tic acid derivatives on angiotensin I induced pressor response in rats. (O), compound $3,0.3 \mathrm{mg} / \mathrm{kg}$, i.v., $\mathrm{n}=2$; $(\triangle)$. compound $4.0 .3 \mathrm{mg} / \mathrm{kg}$, i.v., $n=3$; ( $)$ : compound $5,0.3 \mathrm{mg} / \mathrm{kg}, \mathrm{i} . \mathrm{v} ., \mathrm{n}=3:$ ( $\square)$. compound 6. $0.3 \mathrm{mg} / \mathrm{kg}$, i.v., $\mathrm{n}=3$; (A). compound $7,0.3 \mathrm{mg} /$ $\mathrm{kg}$, i.v., $n=6$; (O), CV-3317-COOH (compound 1b). $0.3 \mathrm{mg} / \mathrm{kg}$, i.v., $\mathrm{n}=3$.
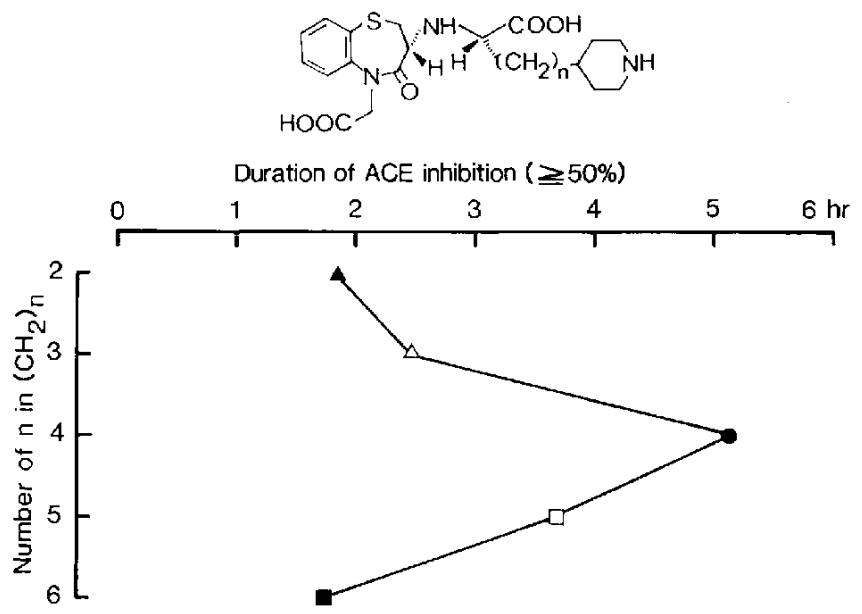

Fig. 4. Relationship between duration of $A C E$ inhibition and the value of $n$ in $\left(\mathrm{CH}_{2}\right)_{n}$ in rats. Duration of $A C E$ inhibition was measured as the time (hr) required for the inhibited A-I-induced pressor response to recover to $50 \%$ of the control value for $\mathrm{A}-\mathrm{l}$-induced pressor response. ( $\boldsymbol{\Delta}$ ), compound $7.0 .3 \mathrm{mg} /$ $\mathrm{kg}$. i.v., $\mathrm{n}=6$; $(\Delta)$. compound $8,0.3 \mathrm{mg} / \mathrm{kg}$, i.v., $\mathrm{n}=4$; (O), compound $9 \mathrm{a}$ (CV-5975), $0.3 \mathrm{mg} / \mathrm{kg}$, i.v.,

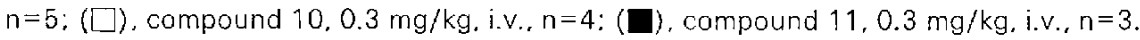


Table 2. Inhibitory effects of stereoisomers of CV-5975 on rabbit lung ACE and angiotensin I (A-I) induced pressor response in rats

\begin{tabular}{|c|c|c|c|c|c|c|c|c|c|}
\hline \multirow[t]{3}{*}{ Compound } & \multicolumn{2}{|c|}{ Configuration } & \multicolumn{2}{|c|}{$\begin{array}{l}\text { Rabbit lung } \\
\text { ACE } \\
\text { inhibition }\end{array}$} & \multicolumn{5}{|c|}{$\begin{array}{l}\% \text { Inhibition of } A-I \text { pressor response at } \\
\text { various times after the administration of } \\
\text { compounds }\end{array}$} \\
\hline & $*$ & $* *$ & & & -- & $\cdots$ & & & - \\
\hline & & & $1 C 50(M)$ & ratio & $\begin{array}{c}\mathrm{mg} / \mathrm{kg} \\
\mathrm{i} . \mathrm{v} .\end{array}$ & 10 & 30 & 60 & $120 \mathrm{~min}$ \\
\hline & & & $-\quad \cdot \quad--$ & $-\cdots-$ & $\ldots \quad \cdots$ & & - & & $\cdots \quad-$ \\
\hline $9 a(C V-5975)$ & $R$ & S & $3.1 \times 10^{-9}$ & $1 / 1$ & 0.3 & $96 \pm 4 \star$ & $99 \pm 1$ & $93 \pm 3$ & $91 \pm 4$ \\
\hline $9 b$ & $R$ & $\mathrm{R}$ & $3.1 \times 10^{-8}$ & $1 / 10$ & 0.3 & $73 \pm 5$ & $34 \pm 5$ & $12 \pm 8$ & $0 \pm 4$ \\
\hline 90 & S & S & $2.9 \times 10^{-7}$ & $1 / 94$ & 0.3 & $3 \pm 6$ & $-4 \pm 5$ & $-5 \pm 6$ & $-11 \pm 6$ \\
\hline $9 d$ & $S$ & $R$ & $6.0 \times 10^{-7}$ & $1 / 194$ & 0.3 & $9 \pm 7$ & $2 \pm 5$ & $-1 \pm 7$ & $-7 \pm 6$ \\
\hline
\end{tabular}

$\star$ mean \pm S.E.M. of 3 to 5 rats.

Table 3. Inhibitory effects of $\mathrm{CV}-5975$ (9a) and its ester (9e) on angiotensin I (A-I) induced pressor response in rats

\begin{tabular}{|c|c|c|c|c|c|c|c|}
\hline \multirow{2}{*}{ Compound } & \multirow{2}{*}{$\mathrm{R}$} & Dose & \multicolumn{5}{|c|}{$\begin{array}{l}\% \text { Inhibition of A-I pressor response at various times } \\
\text { after the administration of compounds }\end{array}$} \\
\hline & & p.o. & $1 / 3$ & 1 & 3 & 5 & $7 \mathrm{hr}$ \\
\hline$\ldots \ldots$ & $\cdots \quad-\ldots$ & & $-\quad \ldots$ & & $\cdots$ & $\therefore$ & - \\
\hline $9 a(C V-5975)$ & $\mathrm{H}$ & 3 & $70 \pm 12$ & $84 \pm 10$ & $91 \pm 2$ & $88 \pm 3$ & $84 \pm 7$ \\
\hline $9 \mathrm{e}$ & $\mathrm{C}_{2} \mathrm{H}_{5}$ & 3 & $0 \pm 5$ & $-1 \pm 2$ & $15 \pm 5$ & $12 \pm 4$ & $13 \pm 5$ \\
\hline
\end{tabular}

mean \pm S.E.M. of 4 to 5 rats.

response in rats. As shown in Table 2, the 3 isomers of CV-5975 (compound 9a) showed only very weak inhibition in both assays.

4. Oral absorption of CV-5975 and its ester form: CV-5975 (compound 9a) and its ester form (compound $9 \mathrm{e}$ ) were administered orally to rats at $3 \mathrm{mg} / \mathrm{kg}$ and their inhibitory activities were evaluated. CV-5975 (compound 9a) exhibited potent ACE inhibitory activity, but its ester form did not (Table 3).

\section{Discussion}

Conformational examination using a Dreiding model indicated that $\mathrm{CV}-3317-\mathrm{COOH}$ (compound 1b in Fig. 1) is expected to be stable, because it has a low level of nonbonded interactions. Although the tricyclic fused compound (compound 2) clearly corresponds to $\mathrm{CV}-3317-\mathrm{COOH}$, the structure was rather complicated to synthesize. Carboxyl, amido, amino and hydrophobic moieties are located in the same positions in the computer-drawn structure of alanylproline, alanyl indanyl glycine and (R)-3-amino-4oxo-2.3,4,5-tetrahydro-1,5-benzothiazepine5 -acetic acid. The test compounds were designed to incorporate conformational restriction in rigid skeletons.

Compounds $3,4,5,6$ and 7 were highly 
active against rabbit lung $A C E$, and their potencies were comparable to that of $\mathrm{CV}$ $3317-\mathrm{COOH}$ (compound 1b, Table 1) (23). Based on the finding that compound 3 and its derivatives showed potent ACE inhibitory activity, we speculated that the functional groups on compound 3 such as carboxyl, amido, amino and hydrophobic moieties might be located in favorable positions for binding to active sites in ACE. The structureactivity relationships of these compounds provided some information on the structural requirements of the substituent $R$ for prolonging the in vivo ACE-inhibitory activity. A piperidylpentylamino derivative induced the longest lasting inhibition of ACE in the series of benzoxazepine derivatives examined.

CV -5975 has 3 stereoisomers, and these 3 isomers showed only weak inhibition for $A C E$. The importance of chiral requirements for activity has been established in several studies on ACE inhibitors $(5,8,19,23-26)$.

It is known that enalapril and delapril $\mathrm{HCl}$. which are monoacids, are orally well absorbed pro-drugs $(9,20)$ and that the corresponding diacids produced after deesterification in vivo are the active compounds. CV-5975 exhibited potent ACE inhibitory activity, but its ester form did not. In contrast to enalapril and delapril $\mathrm{HCl}, \mathrm{CV}-5975$ itself has two free carboxy groups and it is absorbed in an active form.

Maximum duration of activity was observed with the piperidylpentylamino derivatives out of the series of benzoxazepine derivatives examined (24). The distance (9-10 $\AA$ from a Dreiding model) between the two nitrogen atoms of the piperidylpentylamino moiety is almost equal to that of the 6 or 7 alkylene chain in the aminooctyl moiety which had the longest duration of activity among the series of aminoalkylamino derivatives (25). This finding indicates that a basic amino group is essential for longlasting inhibitory activity in vivo. Although the role of the nitrogen atom in prolonging the duration of action is not yet clear, it might be related to the existence of an additional binding site on $A C E$ and/or it may confer increased affinity to ACE (27).

Acknowledgments: We thank Miss M. Ojima and Mr. H. Nakagawa for technical assistance in the biological assays and thank Mr. M. Kori for synthesizing the test compounds.

\section{References}

1 Piquilloud, $Y$., Reinharz, $A$. and Roth, $\mathbf{M}$ : Studies of the angiotensin converting enzyme with different substrates, Biochem. Biophys. Acta 206, 136-142 (1970)

2 Skeggs, L.T., Kahn, J.R. and Shumway, N.P.: The preparation and function of the hypertensinconverting enzyme. J. Exp. Med. 103, 295-299 (1956)

3 Cushman, D.W. and Cheung, H.S.: Spectrophotometric assay and properties of the angiotensin-converting enzyme of rabbit lung. Biochem. Pharmacol. 20, 1637-1648 (1971)

4 Yang, H.Y.T., Erdos, E.G. and Levin, Y.: Characterization of a dipeptide hydrolase (kininase I1: angiotensin converting enzyme). J. Pharmacol. Exp. Ther. 177, 291-300 (1971)

5 Ondetti, M.A., Rubin, B. and Cushman, D.W.: Design of specific inhibitors of angiotensin converting enzyme: a new class of orally active antihypertensive agents. Science 196, 441-444 (1977)

6 Rubin, B., Laffan, R.J., Kotler, D.G., O'Keefe, E.H., Demaio, D.A. and Goldberg, M.E.: SQ 14.225 (D-3-mercapto- 2 - methylpropanoy! - L proline), a novel orally active inhibitor of angiotensin l-converting enzyme. J. Pharmacol. Exp. Ther. 204, 271-280 (1978)

7 Laffan, R.J., Goldberg, M.E., High, J.P., Schaeffer, T.R., Waugh, M.H. and Rubin, B.: Antihypertensive activity in rats of $S O 14,225$. an orally active inhibitor of angiotensin 1 converting enzyme. J. Pharmacol. Exp. Ther. 204, 281-288 (1978)

8 Patchett, A.A., Harris, E., Tristram, E.W., Wyvratt, M.J., Wu, M.T., Taub, D., Peterson, E.R., Ikeler, T.J., Ten Broeke, J., Payne, L.G., Ondexya, D.L., Thorsett, E.D., Greenlee, W.J., Lohr, N.S., Hoffsommer, R.D., Joshua, H., Ruyle, W.V., Rothrock, J.W., Aster, S.D., Maycock. A.L., Robinson, F.M., Hirschmann, R., Sweet, C.S., Ulm, E.H., Gross, D.M., Vassil, T.C. and Stone, C.A.: A new class of angiotensin converting enzyme inhibitors. Nature 288, 280-283 (1980)

9 Gross, D.M., Sweet, C.S., UIm, E.H., Backlund, E.P., Morris, A.A., Weitz, D., Bohn, D.L., Wenger, H.C., Vassil, T.C. and Stone, C.A.: Effect of N-[(s)-1-carboxy-3-phenylpropyl]-L-Ala-L-Pro and its ethyl ester (MK-421) on angiotensin converting enzyme in vitro and angiotensin I pressor responses in vivo. J. Pharmacol. Exp. Ther. 216, 552-557 (1981) 
10 Sweet, C.S., Gross, D.M., Arbegast, P.T., Leegaul, S., Britt, P.T., Ludden, C.T., Weitz, D. and Stone, C.A.: Antihypertensive activity of $\mathrm{N}$ [(s) - 1 - (ethoxycarbonyl) - 3-phenylpropyl] - L-AlaL-Pro (MK-421), an orally active converting enzyme inhibitor. J. Pharmacol. Exp. Ther. 216 , $558-566$ (1981)

11 Heel, R.C., Brogden, R.N., Speight, T.M. and Avery, G.S.: Captopril: a preliminary review of its pharmacological properties and therapeutic efficacy. Drugs 20, 409-452 (1980)

12 Gavras, H., Biollaz, J., Waeber, B., Brunner, H.R., Gavras, I. and Davis, R.O.: Antihypertensive effect of the new oral angiotensin converting enzyme inhibitor "MK-421". Lancet ii, 543-546 (1981)

13 Bravo, E.L. and Tarazi, R.C.: Converting enzyme inhibition with an orally active compound in hypertensive man. Hypertension 1, 39-46 (1979)

14 Wilkins, L.H., Dustan, H.P., Walker, J.F. and Oparil, S.: Enalapril in low-renin essential hypertension. Clin. Pharmacol. Ther. 34, 297-302 (1983)

15 Combes, B.J.D., Turini, G.A., Brunner, H.R., Porchet, M., Chen, D.S. and Sen, S.B.: CGS 13945: a new orally active angiotensin converting enzyme inhibitor in normal volunteers. J. Cardiovasc. Pharmacol. 5, 511-516 (1983)

16 Chen, D.S., Watkins, B.E., Ku, E.C., Doston, R.A. and Burrell, R.D., Jr.: Pharmacological profiles of two new angiotensin-converting enzyme (ACE) inhibitors: CGS 13945 and CGS 13934. Drug Dev. Res. 4, 167-178 (1984)

17 Becker, R.H.A., Scholkens, B.A., Metzger, $M$. and Schuze, K.J.: Pharmacological properties of the new orally active angiotensin converting enzyme inhibitor 2-[N-[(S)-1-ethoxycarbonyl3-phenylpropyl] - L - alany!] - (1s.3s,5s) - 2-azabi cyclo-[3.3.0.]-octane-3-carboxylic acid (Hoe 498). Arzneimittelforschung 34, 1411-1416 (1984)

18 Sybertz, E.J., Baum, T., Ahn, H.S., Nelson, S., Eynon, E., Desiderio, D.M., Pula, K., Becker, F., Sabin, C., Moran, R., Vliet, G.V., Kastner, B. and Smith, E.: Angiotensin-converting enzyme inhibitory activity of $\mathrm{SCH} 31846$, a new nonsulthydryl inhibitor. J. Cardiovasc. Pharmacol. 5 , 643-654 (1983)
19 Petrillo, E.W., Jr. and Ondetti, M.A.: Angiotensinconverting enzyme inhibitors: Medicinal chemistry and biological actions. Med. Res. Rev. 2, $1-41(1982)$

20 Inada, Y., Terashita, Z., Imura, Y., Tanabe, M., Nishikawa, K. and Kikuchi, S.: Inhibition of angiotensin converting enzyme by $\mathrm{CV}-3317$, a nonsulfhydry! compound. Japan. J. Pharmacol. 42, 99-108 (1986)

21 Inada, Y., Tanabe, M., Shibouta, Y., Kawazoe, K., Nishikawa, K. and Kikuchi, S.: Antihypertensive action of a non-sulfhydryl angiotensin converting enzyme inhibitor ( $C V-3317$ ) in various hypertensive models. Japan. J. Pharmacol. 42, 1-8 (1986)

22 Wallace, K.B., Bailie, M.D. and Hook, J.B.: Angiotensin-converting enzyme in developing lung and kidney. Am. J. Physiol. 234, R141R1 45 (1978)

23 Itoh, K., Kori, M., Inada, Y., Nishikawa, K., Kawamatsu, Y. and Sugihara, H.: Synthesis and angiotensin converting enzyme inhibitory activity of 1,5-benzothiazepine and 1,5-benzoxazepine derivatives. I. Chem. Pharm. Bull. (Tokyo) 34, 1128-1147 (1986)

24 Itoh, K., Kori, M., Inada, Y., Nishikawa, K., Kawamatsu, Y. and Sugihara, H.: Synthesis and angiotensin converting enzyme inhibitory activity of 1,5-benzothiazepine and 1,5-benzoxazepine derivatives. III. Chem. Pharm. Bull. (Tokyo) 34, 3747-3761 (1986)

25 Itoh, K., Kori, M., Inada, Y., Nishikawa, K., Kawamatsu, $Y$. and Sugihara, $H$ : Synthesis and angiotensin converting enzyme inhibitory activity of 1,5-benzothiazepine and 1,5-benzoxazepine derivatives. II. Chem. Pharm. Bull. (Tokyo) 34, 2078-2089 (1986)

26 Wyvratt, M.J. and Patchett, A.A.: Recent development in the design of angiotensinconverting enzyme inhibitors. Med. Res. Rev. 5 , 483-531 (1985)

27 Inada, Y., Tanabe, M., Itoh, K., Sugihara, H. and Nishikawa, K.: Inhibition of angiotensin converting enzyme by (R) - 3-[(S)-1-carboxy-5-(4piperidyl)pentyl] amino-4-oxo-2,3,4,5-tetrahydro-1,5-benzothiazepine-5-acetic acid (CV5975). a non-sulfhydryl compound. Japan. J. Pharmacol. (in press) 